\title{
Efektifitas perawatan kanguru pada bayi prematur: Scoping review
}

\author{
Litri Artiani ${ }^{1 *}$, Sri Ratna Ningsih ${ }^{2}$, Andari Wuri Astuti ${ }^{3}$ \\ 1,2,3 Universitas 'Aisyiyah Yogyakarta
}

\author{
INFORMASI ARTIKEL: \\ Riwayat Artikel: \\ Tanggal diterima: 25 Mei 2021 \\ Tanggal direvisi: 27 Juni 2021 \\ Tanggal dipublikasi: 26 Juli 2021 \\ Kata kunci: \\ Prematur \\ Perawatan Kangguru \\ Efektivitas
}

10.32536/jrki.v5i1.164

Keyword :

Preterm

Kangaroo Care

Effectiveness

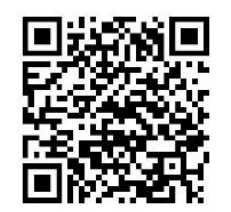

\section{Pendahuluan}

Kelahiran Prematur merupakan salah satu faktor resiko yang mempunyai kontribusi terhadap kematian (Rusmania, 2015). Data menunjukkan angka kematian bayi di dunia pada tahun 2015 sejumlah 31,7 kematian per 1000 kelahiran hidup, sedangkan angka kematian bayi di Asia Tenggara sejumlah 34 kematian per 1000 kelahiran hidup (Mudiyah and Pratomo, 2016).

Penyebab terbanyak kematian neonates adalah Prematuritas dan Berat Badan Lahir Rendah (BLBR), yaitu sebesar 30\% dari seluruh kematian neonatus. Setiap tahun di dunia diperkirakan lahir sekitar 20 juta BBLR, dan 95\% terjadi di negaranegara berkembang (Mudiyah and Pratomo, 2016). Bayi prematur mempunyai BBLR yang cenderung mengalami hipotermi. Hal ini disebabkan karena tipisnya lemak subkutan pada bayi sehingga sangat mudah dipengaruhi oleh suhu lingkungan (Rusmania, 2015).
Pada umumnya perawatan bayi prematur menggunakan inkubator yang merupakan alat yang dirancang khusus untuk membantu terciptanya suatu lingkungan yang optimal, dengan demikian dapat tercipta suhu lingkungan yang optimal pula. Saat bayi sudah di rumah, bayi akan memerlukan intervensi selain incubator untuk menjaga suhu bayi (Sofiani and Asmara, 2014).

Perawatan ibu Kanguru (KMC) adalah terobosan beragam aspek bagi bayi prematur dan BBLR serta orang tua mereka (Charpak et al., 2017). Sentuhan kulit antara bayi dan ibu biasa disebut Kangaroo Care (KC), sudah membuktikan khasiatnya sebagai prosedur penghilang rasa sakit pada bayi, namun masih rendah digunakan dalam praktik klinis (Benoit et al., 2016). Berdasarkan permasalahan yang ada maka penulis tergerak untuk mendalami efektivitas perawatan kanguru pada bayi prematur.

\footnotetext{
*Korespondensi penulis.

Alamat E-mail: litriartianig12@mail.com
} 


\section{Metode penelitian}

Scoping review didefinisikan sebagai jenis sintesis penelitian yang bertujuan untuk memetakan literatur pada topic tertentu atau bidang penelitian dan memberikan kesempatan untuk mengidentifikasi konsep-konsep kunci; kesenjangan dalam penelitian; dan jenis dan sumber bukti untuk menginformasikan praktik, pembuatan kebijakan, dan penelitian (Daudt, Van Mossel and Scott, 2013).

Scoping review sekarang dipandang sebagai pendekatan yang valid dalam hal itu karena sistematis review tidak dapat melakukannya untuk memenuhi tujuan atau persyaratan yang diperlukan pengguna pengetahuan. Sekarang ada panduan yang jelas tentang definisi, bagaimana melakukan scoping review dan langkah-langkah yang terlibat dalam proses scoping review (Munn et al., 2018).

Lima fase utama yang dicakup dalam scoping review, yaitu: (1) mengidentifikasi pertanyaan penelitian, (2) mengidentifikasi studi yang relevan, (3) pemilihan studi, (4) membuat grafik data, dan (5) menyusun, merangkum, dan melaporkan hasilnya. 'Latihan konsultasi' opsional dari kerangka kerja tidak dilakukan. Protokol tinjauan terperinci dapat diperoleh dari penulis utama atas permintaan (Pham et al., 2014).

\section{Mengidentifikasi pertanyaan scoping review}

Untuk mengidentifikasi pertanyaan scoping review serta mengembangkan strategi pencarian digunakan framework Population, Exposure, Outcome, Study Design (PEOS). PEOS dinilai tepat untuk digunakan (Bettany and Saltikov, 2012).

Tabel 1. Framework pertanyaan penelitian

\begin{tabular}{cccc}
\hline $\begin{array}{c}\text { P } \\
\text { (Population) }\end{array}$ & $\begin{array}{c}\text { E } \\
\text { (Exposure) }\end{array}$ & $\begin{array}{c}\text { O } \\
\text { (Outcome) }\end{array}$ & $\begin{array}{c}\text { S (Study } \\
\text { Design) }\end{array}$ \\
\hline Premature & Kangaroo Care & Impact & All study \\
Infant & Kangaroo & Effect & design \\
Premature & Maternal Care & Outcome & \\
Infant & Kangaroo & Consequence & \\
Preterm Baby & Mother Care & & \\
PrematureBa & Skin to Skin & & \\
by & Care & & \\
& & & \\
\hline
\end{tabular}

\section{Mengidentifikasi artikel yang relevan}

Scoping review ini mengidentifikasi artikel yang relevan dengan menentukan kriteria inklusi dan eksklusi dari framework, artikel yang diterbitkan dalam 10 tahun terakhir, berbahasa Inggris dan Indonesia, artikel hasil penelitian atau original, artikel negara modern dan berkembang. Artikel opini/komentar yang dikecualikan adalah artikel review dan pelaporan atau artikel buku.

Langkah kedua adalah menentukan kata kunci yang digunakan dalam pencarian literatur, kata kunci yang dirancang dan difokuskan pada kerangka yang diperluas dengan menentukan sinonim melalui Thesaurus dan Booleant. Oleh karena itu, kata kunci yang digunakan dalam scoping review ini terdiri dari Preterm infant $O R$ "preterm baby" $O R$ "premature infant" $O R$ "preterm baby" OR "premature baby" AND "Kangaroo Care" OR "Kangaroo Mother Care" OR "Skin to Skin Care" AND "Impact" OR "Effect" OR "Outcome". Langkah terakhir adalah memasukkan kata kunci tersebut ke dalam mesin pencarian pada tiga basis data, yaitu: PubMed, Science Direct, dan Wiley. 


\section{Seleksi Artikel}

Ditemukan 427 artikel berdasarkan pencarian database ketiga yaitu PubMed, Science Direct, dan Wiley, kemudian artikel disimpan di bibliografi engine Mendeley, setelah itu skrining duplikat artikel sehingga ditemukan 293 artikel. Terdapat 232 artikel yang tidak relevan, sehingga terdapat 61 teks yang lengkap dan relevan. Setelah itu terdapat 41 teks yang dikeluarkan karena tidak sesuai dengan criteria inklusi, sehingga terdapat 20 artikel yang dipilih sesuai dengan criteria inklusi. Langkah selanjutnya adalah melakukan penilaian kritis. Hasil dari total artikel dan proses penyaringan digambarkan dalam Flowchart PRISMA.

PRISMA Flowchart merupakan Preferred Reporting Items for Systematic Reviews and Meta Analysis, digunakan untuk membantu penulis menyediakan laporan yang lebih lengkap, yang memungkinkan pembaca untuk memiliki semua informasi yang dibutuhkan untuk menilai relevansi hasil dalam Systematic Review (SR) dan Meta Analysis (MA)(Leclercq et al., 2019). PRISMA dinilai tepat digunakan karena penggunaanya dapat meningkatkan kualitas pelaporan publikasi. Data disaring sesuai dengan kriteria yang peneliti tentukan. Adapun tahap-tahap penyaringan data sebagai berikut:

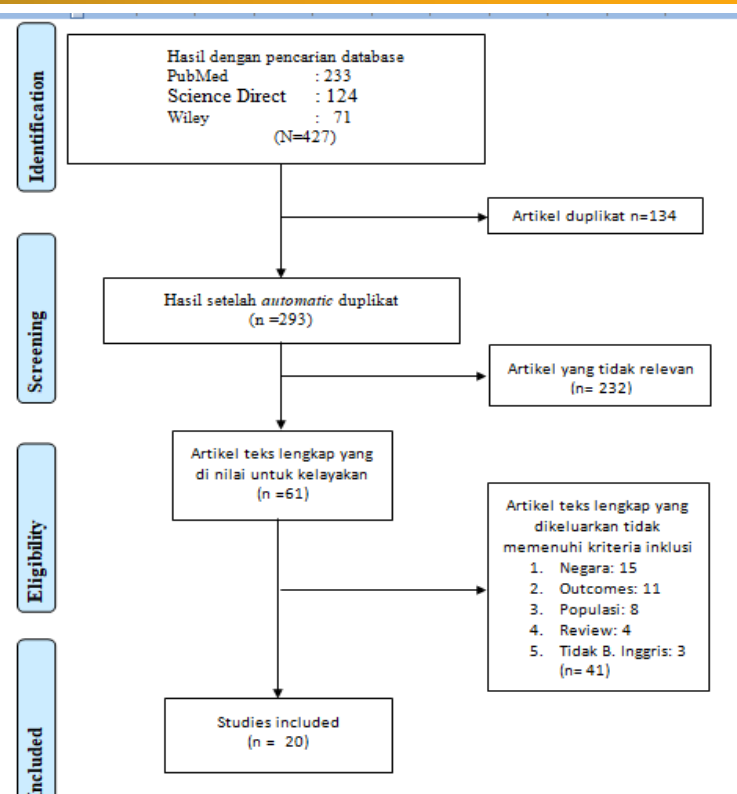

Gambar 1. PRISMA Flowchart 


\section{Data Charting}

Data charting digunakan untuk menggolongkan beberapa poin atau bagian dari artikel seperti judul penelitian, tujuan penelitian, desain penelitian, jumlah sample, dan hasil atau temuan dari penelitian tersebut. Setelah dianalisis dan dievaluasi dari beberapa point diatas maka hasil pengumpulan dari ekstraksi data sesuai dengan judul Scoping review pada pada tabel 2.

\begin{tabular}{|c|c|c|c|c|c|}
\hline No & $\begin{array}{l}\text { Author/ year/ } \\
\text { Country/Grade/ } \\
\text { Method }\end{array}$ & Objective & Data Collection & Participant/number of samples & Finding \\
\hline A1. & $\begin{array}{l}\text { Ndelema et } \\
\text { al/2016/Africa/A/ } \\
\text { Retrospective }\end{array}$ & $\begin{array}{l}\text { Untuk mengetahui apakah KMC } \\
\text { berteknologi rendah dapat } \\
\text { menurunkan angka kematian } \\
\text { neonatal pada bayi prematur }\end{array}$ & $\begin{array}{l}\text { Menggunakan data } \\
\text { neonatal rutin }\end{array}$ & 437 bayi prematur & $\begin{array}{l}\text { Studi ini menunjukkan tingkat kelangsungan } \\
\text { hidup yang tinggi diperoleh meski tanpa } \\
\text { peralatan berteknologi tinggi atau perawat } \\
\text { spesialis neonatal. }\end{array}$ \\
\hline A2. & $\begin{array}{l}\text { Bera et } \\
\text { al/2014/India/A/ RCT }\end{array}$ & $\begin{array}{lr}\text { Untuk mengetahui } & \text { pengaruh } \\
\text { KMC berkelanjutan } & \text { terhadap } \\
\text { pertumbuhan } & \text { dan } \\
\text { perkembangan BBLR } & \end{array}$ & $\begin{array}{l}\text { Data diambil di RS SSKM yang } \\
\text { setuju untuk melaksanakan KMC }\end{array}$ & 500 bayi prematur dan ibu bayi & $\begin{array}{l}\text { Bayi KMC mampu secara fisik menyerupai bayi } \\
\text { normal pada usia } 39 \text { minggu ke atas. } \\
\text { Pertumbuhan dan perkembangan tim KMC } \\
\text { lebih baik dari pada tim kontrol konvensional. }\end{array}$ \\
\hline A3. & $\begin{array}{l}\text { Cong et } \\
\text { al/2009/United } \\
\text { States/A/RCT }\end{array}$ & $\begin{array}{l}\text { Untuk melihat keberhasilan } \mathrm{KC} \\
\text { dalam meningkatkan } \\
\text { keseimbangan respon otonom } \\
\text { nyeri tusuk tumit dibandingkan } \\
\text { dengan metode standar }\end{array}$ & $\begin{array}{l}\text { Diambil dari data demografis dan } \\
\text { mode total invasif sebelumnya }\end{array}$ & 14 bayi prematur & $\begin{array}{l}\text { Keseimbangan bayi lebih baik dalam menangga } \\
\text { pi KC dibandingkandengankondisi IC. KC } \\
\text { membantumengurangi proses reaksifisiologis } \\
\text { yang dapatmenyakitkanbagibayiprematur. }\end{array}$ \\
\hline A4. & $\begin{array}{l}\text { Gathwala et } \\
\text { al/2010/India/B/RCT }\end{array}$ & $\begin{array}{l}\text { Hal ini untuk mengetahui hasil } \\
\text { penerapan KMC pada bayi LWB } \\
\text { untuk } r \text { meningkatkan } \\
\begin{array}{l}\text { pertumbuhan } \\
\text { keberhasilan dan respon } \\
\text { menyusui }\end{array}\end{array}$ & $\begin{array}{l}\text { Penelitian ini dilakukan oleh Divisi } \\
\text { Neonatologi, } \quad \text { Departemen } \\
\text { Kesehatan Anak }\end{array}$ & 100 bayi prematur & $\begin{array}{l}\text { Peningkatanberat badan rata-rata pada } \\
\text { kelompokstudisecarasignifikanlebihtinggidarip } \\
\text { ada pada kelompokstudi. Suhu pada kelompok } \\
\text { KMC secarasignifikanlebihtinggidibandingkan } \\
\text { pada kelompokperawatanrutin. }\end{array}$ \\
\hline A5. & $\begin{array}{l}\text { Chidambaram et } \\
\text { al/2014/India/A/Cross } \\
\text { Section }\end{array}$ & $\begin{array}{l}\text { Untuk mengetahui lebih lanjut } \\
\text { tentang KMC dalam } \\
\text { mengurangi rasa sakit setelah } \\
\text { bayi prematur diberikan tusuk } \\
\text { tumit }\end{array}$ & $\begin{array}{l}\text { Dilakukan di rumah sakit } \\
\text { pendidikan perawatan tersier }\end{array}$ & 100 bayi prematur & $\begin{array}{l}\text { Setelah prosedur tusuk tumit, skor PIPP secara } \\
\text { signifikan lebih rendah pada kelompok KMC. } \\
\text { KMC efektif meredakan nyeri akibat tusukan } \\
\text { tumit pada bayi prematur. }\end{array}$ \\
\hline
\end{tabular}


A6. Vitner et al/2018/USA/A/RCT

\section{Untuk melihat perubahan yang}

terjadi pada bayi dan orang tua

dari kadar oksitosin saliva (OT)

dan kortisol saliva (SC) selama

KMC

A7. Flacking al/2011/Sweden/A

et Untuk memahami penggunaan KMC dan hubungannya dengan ibu yang menyusui sangat prematur dan bayi prematur berusia 1 sampai 6 bulan.

A8. Choudhary

et Untuk melihat pengaruh KMC Penelitian dilakukan di Bagian al/2016/India/B/ Cross terhadap respon nyeri, respon Sectional

\section{A9. Korra}

al/2014/Egypt/A/

Perspective

\section{et}

perilaku dan perubahan

fisiologis terhadap rangsangan

nyeri pada bayi prematur

Untuk mengevaluasi penerapan KMC terhadap perubahan aliran darah otak (CBF) di arteri serebral tengah, sebelum dan setelah 30 menit pada bayi prematur

A10. Morlacchi et al/2016/Italia/A/Perspe ctive

Menilai

keberhasilan penerapan KMC dan partisipasi orang tua dalam memberikan makanan oral lengkap untuk bayi prematur

A11. Gao et al/2015/China/A/RCT

Untuk mengukur efektivitas KMC yang dilakukan secara berulang terhadap nyeri tumit pada bayi prematur

A12. Karlsson et al/2012/Sweden/A/ Retrospective Study pengobatan SSC
Kaji ulang catatan medis bayi dan Kaji ulang catatan
riwayat orang tua

Data KMC dilihat dari durasi kontak kulit harian bayi prematur yang dirawat di empat unit neonatal di rumah sakit Swedia dan informasi diri dari orang tua. Neonatal dari Departemen Pediatri

Akses informasi tentang bayi prematur yang direkrut dari unit neonatal.

Diambil dari persetujuan dewan 81 bayi prematur peninjau institusi di Poliklinik dan persetujuan tertulis dari orang tua bayi

Direkrut dari data bayi prematur di 80 bayi prematur NICU tingkat III rumah sakit pendidikan besar

Data diambil dari pemantauan rutin 26 bayi prematur proses perawatan klinis bayi
28 bayi prematur dan orang tua bay

103 bayi prematur dan ibu bay

110 bayi prematur

60 bayii prematur

(a)

Kadar kortisol saliva ibu, ayah, dan bayi meningkat secara signifikan selama pemberian SSC. Setelah SSC, angka CS bayi menurun secara signifikan. SSC menghubungkan orang tua dan bayi dengan respons biobehavioral.

Penerapan KMC pada pasangan VPT yang sedang menyusui lebih banyak menghabiskan waktu menyusui dalam sehari. Studi ini menunjukkan pentingnya KMC selama menyusui pada mitra VPT

Kemanjuran KMC pada skor nyeri setelah proses tongkat tumit secara signifikan lebih rendah.

Peningkatan kecepatan diastolik akhir \& kecepatan rata-rata 30 menit adalah hasil dari KMC. Perubahan ini menunjukkan peningkatan CBF yang signifikan.

Pemberian KMC sejak awal dan melibatkan orang tua dalam pemberian makan bayi mencapai hasil positif dalam pemberian makanan oral mandiri.

Perbandingan detak jantung bayi prematu antara kedua kelompok secara signifikan lebih rendah pada kelompok KMC, dan durasi menangis dan senyum wajah secara signifikan lebih pendek pada kelompok KMC.

Selama SSC, suhu tubuh bayi bisa dijaga dengan normal. SSC dapat meningkatkan penurunan suhu kulit. Kelembaban dan suhu lingkungan pada perlakuan inkubator lebih tinggi dibandingkan selama SSC. 


\begin{tabular}{|c|c|c|c|c|c|}
\hline A13. & $\begin{array}{l}\text { Ramani et } \\
\text { al/2018/Zambia/A/RCT }\end{array}$ & $\begin{array}{l}\text { Untuk menguji hipotesis bahwa } \\
\text { KMC lebih baik dilakukan saat } \\
\text { lahir atau } 1 \text { jam setelah } \\
\text { neonatus prematur lahir dan } \\
\text { mengurangi hipotermia sedang } \\
\text { atau berat. }\end{array}$ & $\begin{array}{l}\text { RCT terpusat tunggal ini dilakukan } \\
\text { di Zambia }\end{array}$ & 165 bayi prematur & $\begin{array}{l}\text { KMC dikombinasikan dengan perawatan } \\
\text { termoregulasi standar yang dilakukan } \\
\text { sebanyak mungkin saat lahir atau } 1 \text { jam setelah } \\
\text { lahir mengurangi hipotermia sedang atau berat } \\
\text { pada bayi cukup bulan dibandingkan dengan } \\
\text { hanya melakukan perawatan termoregulasi } \\
\text { standar. }\end{array}$ \\
\hline A14. & $\begin{array}{l}\text { Cho et al/2016/South } \\
\text { Korea/A/ Quasi } \\
\text { experimental }\end{array}$ & $\begin{array}{l}\text { Untuk menilai pengaruh KC } \\
\text { pada sistem organ bayi } \\
\text { prematur, pelekatan ibu-bayi, } \\
\text { dan tingkat stres ibu. }\end{array}$ & Diambil dari data bayi prematur & 40 bayi prematur & $\begin{array}{l}\text { Tingkat pernapasan antara kedua kelompok } \\
\text { setelah menerima pengobatan Kanguru } \\
\text { berbeda secara signifikan. Kelompok } \\
\text { eksperimen memiliki skor yang lebih tinggi } \\
\text { pada kedekatan ibu dan skor yang lebih rendah } \\
\text { pada respon stres ibu daripada kelompok } \\
\text { kontrol. }\end{array}$ \\
\hline A15. & $\begin{array}{l}\text { Feldman et } \\
\text { al/2014/Israel/A/RCT }\end{array}$ & $\begin{array}{l}\text { Untuk mengetahui perbaikan } \\
\text { fisik bayi dengan } \\
\text { mengaplikasikan kontak kulit } \\
\text { ibu dengan kulit bayi prematur } \\
\text { dapat bermanfaat dalam waktu } \\
\text { yang lama. }\end{array}$ & $\begin{array}{l}\text { Data dikumpulkan di dua rumah } \\
\text { sakit }\end{array}$ & 73 bayi prematur & $\begin{array}{l}\text { Kecemasan ibu menurun, fungsi otonom } \\
\text { meningkat, dan sikap ketertarikan ibu pada } \\
\text { masa antepartum. Pada usia } 10 \text { tahun, anak- } \\
\text { anak yang menerima KC menunjukkan reaksi } \\
\text { stres yang berkurang, RSA yang lebih baik, } \\
\text { tidur yang teratur, dan kontrol kognitif yang } \\
\text { lebih baik. }\end{array}$ \\
\hline A16. & $\begin{array}{l}\text { Elfarrashet } \\
\text { al/2019/Egypt/A/RCT }\end{array}$ & $\begin{array}{l}\text { Untuk mengetahui pengaruh } \\
\text { KC dan durasinya terhadap } \\
\text { kinerja neurobehavioral, reaksi } \\
\text { stres dan tanda vital pada bayi } \\
\text { prematur }\end{array}$ & Data dikumpulkan di NICU & 120 bayi prematur & $\begin{array}{l}\text { Kelompok KC mendapat skor lebih tinggi pada } \\
\text { perhatian, stimulasi, regulasi, refleks } \\
\text { suboptimal, dan kualitas gerakan. serta skor } \\
\text { kelompok KC lebih rendah dalam penanganan, } \\
\text { stimulasi, dan kelesuan daripada kelompok } \\
\text { kontrol. perbedaan antara kedua kelompok } \\
\text { terlihat setelah } 7 \text { hari }\end{array}$ \\
\hline A17. & $\begin{array}{l}\text { Heidarzadeh et } \\
\text { al/201/Iran/A/Cross } \\
\text { Sectional }\end{array}$ & $\begin{array}{l}\text { Untuk mengevaluasi efek KMC } \\
\text { pada bayi yang mendapat ASI } \\
\text { eksklusif di rumah }\end{array}$ & $\begin{array}{l}\text { Data diambil dari NICU antara Mei } \\
2008 \text { dan Mei } 2009\end{array}$ & 251 bayi prematur & $\begin{array}{l}\text { Bayi yang mendapat KMC mengalami } \\
\text { peningkatan ASI sebanyak } 4,1 \text { kali selama di } \\
\text { rumah. }\end{array}$ \\
\hline A18. & $\begin{array}{l}\text { Mitchell et } \\
\text { al/2013/USA/A/RCT }\end{array}$ & $\begin{array}{l}\text { Untuk melihat perbandingan } \\
\text { antara inkubator standar versus } \\
\text { pengobatan KC pada kejadian } \\
\text { bradikardia dan desaturasi } \\
\text { oksigen pada bayi prematur }\end{array}$ & $\begin{array}{l}\text { Data diambil dari NICU di Rumah } \\
\text { Sakit }\end{array}$ & 38 bayi prematur & $\begin{array}{l}\text { Insiden bradikardia pada kelompok bayi KMC } \\
\text { lebih sedikit dibandingkan dengan inkubator. } \\
\text { Bayi yang menerima KMC mengalami deplesi } \\
\text { oksigen yang lebih sedikit dibandingkan } \\
\text { dengan bayi yang berada di inkubator. }\end{array}$ \\
\hline
\end{tabular}


A19. Parsa et al/2012/Iran/A/Quas experimental

Untuk menilai pengaruh KMC pada perubahan fisiologis pada bayi prematur

\section{Data}

\section{ge}

100 bayi prematur

al/2015/Brazil/A/Prosp

ective cohort
Untuk menilai efek KMC di PI Data diambil dari PI yang diterima 61 bayi prematur

antara 36 dan 41 minggu pasca- di NICU

konseptual (PCA)
Ada perbedaan yang signifikan antara kedua kelompok dalam grafik fisiologis. Hasi penelitian ini menunjukkan bahwa KMC berpengaruh terhadap peningkatan indeks fisiologis bayi prematur.

Kualitas pergerakan pada bayi yang mendapat KMC terlihat lebih tinggi dan tanda stres pada bayi dinilai lebih rendah 


\section{Menyusun, merangkum dan melaporkan hasil}

Sama dengan apa yang telah dilakukan (Colquhoun et al., 2014), penulis mengambil pendekatan tiga fase untuk mengumpulkan, meringkas, dan melaporkan hasil. Pertama, membuat analisis numerik deskriptif dengan mencantumkan karakteristik artikel. Kedua, menilai kekuatan dan kelemahan literatur melalui analisis tematik dari studi yang dilampirkan dalam laporan. Langkah terakhir adalah mengkaji implikasi temuan dalam kaitannya dengan penelitian, praktik, dan kebijakan di masa mendatang.

\section{Hasil dan Diskusi}

Artikel yang digunakan untuk scoping review ini diambil dari 11 Negara Maju dan 9 Negara Berkembang. Artikel terpilih menjadi sasaran penilaian kritis menggunakan Joana Brigs Institute (JBI) untuk menilai kualitas artikel, sehingga 18 artikel diklasifikasikan sebagai Grade A dan 2 artikel diklasifikasikan sebagai Grade B. Berdasarkan metode penelitian, 9 artikel Metode penelitian yang digunakan Randomized Controlled Trials, 6 artikel dengan metode Cohort Study, 3 artikel dengan metode penelitian Cross Sectional, dan 2 artikel dengan metode penelitian Quasieksperimental.

\section{Article Characteristics}

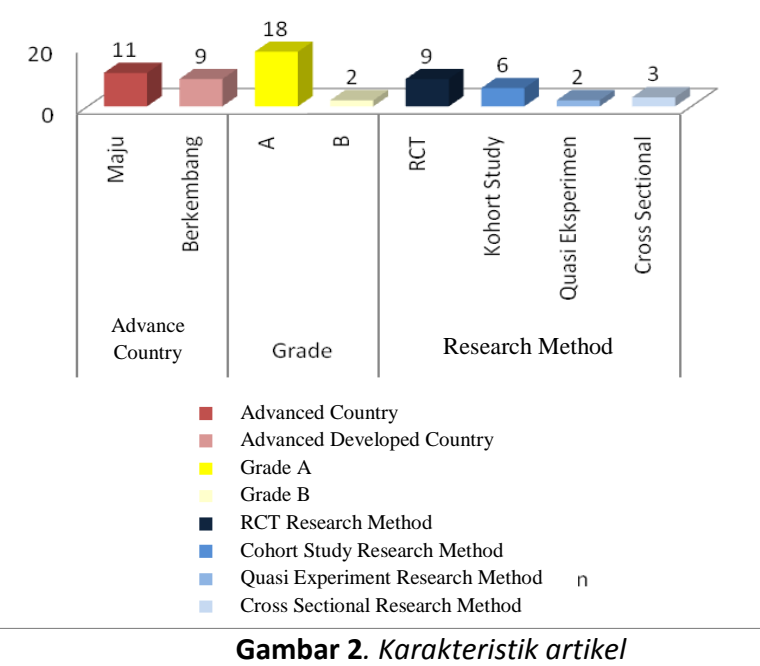

Pemetaan Tema

Table 3. Analisis tema

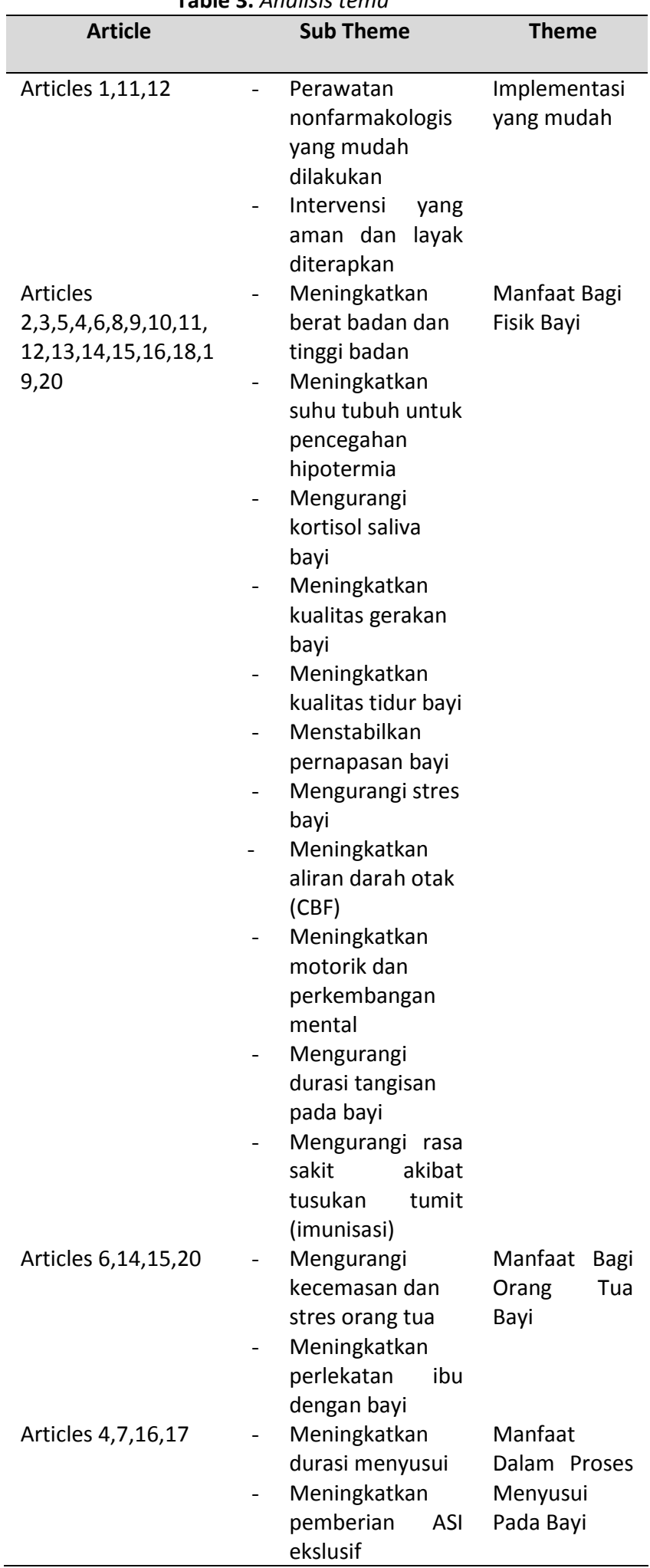




\section{Implementasi yang mudah}

Mengingat banyaknya prosedur invasif yang merupakan bagian dari perawatan klinis pada bayi prematur, membuat sebagian besar ibu lebih memilih memberikan kenyamanan bagi bayi mereka pada saat dilakukan proses yang menyakitkan. KMC merupakan alternative analgesik yang aman dan layak bagi bayi premature (Gao et al., 2015).

KMC adalah intervensi non-farmakologis yang paling mudah melibatkan orang tua untuk mengendalikan nyeri prosedural yang dapat diterapkan untuk menjaga kestabilan fisik atau perilaku pada bayi premature mereka (Choudhary et al., 2016). Setelah mendapat perawatan kanguru, tingkat kelangsungan hidup bayi prematur saat keluar dari rumah sakit lebih tinggi. Tanpa peralatan teknologi yang canggih atau staf dokter spesialis neonatal tingkat kelangsungan hidup yang tinggi dapat dipahami (Ndelema et al., 2016).

Angka kematian neonatal menurun lebih jauh selama 7 hari setelah Pelatihan ENC (kewaspadaan universal dan kebersihan, perawatan neonatal rutin, resusitasi, termoregulasi, menyusui, Perawatan Kangguru, perawatan bayi kecil, dan penyakit umum) terhadap bidan di klinik. Pelatihan dasar tambahan dapat mengurangi angka kematian di masa depan (Carlo et al., 2010).

\section{Manfaat untuk fisik bayi}

Bayi prematur dapat tumbuh melebihi bayi normal, meskipun mereka pasti berukuran lebih kecil saat lahir. Bayi dalam kelompok KMC menunjukkan pertumbuhan dan perkembangan fisik yang lebih baik (Bera et al., 2014). Inisiasi dini KMC dan keterlibatan awal orang tua dalam pemberian makan bayi akan berpengaruh positif terhadap pencapaian pemberian makanan oral mandiri pada bayi prematur (Morlacchi et al., 2018).

SSC dapat digunakan dengan aman pada bayi yang sangat prematur. Konduksi panas dari orang tua ke bayi selama SSC dapat ditoleransi tinggi yang berguna untuk mengimbangi peningkatan kehilangan panas evaporatif dan konvektif (Karlsson et al., 2012). Durasi KMC yang baik setidaknya $80 \%$ dari waktu atau setidaknya 9 jam pada hari kelahiran efektif dalam mencegah hipotermia pada bayi termometer (Ramani et al., 2018).

Efek jangka panjang dari intervensi berbasis sentuhan awal pada organisasi fisiologis anak-anak dan kontrol perilaku memiliki implikasi yang menonjol untuk praktik perawatan bayi prematur (Feldman, Rosenthal and Eidelman, 2014). Efek KMC khususnya adalah peningkatan indeks fisiologis. Oleh karena itu, KMC direkomendasikan sebagai salah satu perawatan rutin bayi prematur (Parsa et al., 2018).

Selain bermanfaat sebagai termogulator, KC juga meningkatkan ikatan kasih sayang antara ibu dan bayi agar berat badan bayi bertambah. KC juga memudahkan pemberian nutrisi, mencegah infeksi dan menekan biaya perawatan dini (Ningsih, Suryantoro and Nurhidayati, 2020). PT yang diserahkan ke KMC menunjukkan kualitas pergerakan yang lebih tinggi dan skor yang lebih rendah dalam kaitannya dengan tanda-tanda stres. PT yang diserahkan ke KMC, dibandingkan dengan yang tidak diserahkan, memiliki kinerja neurobehavior yang lebih baik antara 36 dan 41 minggu setelah usia konseptual (Yelmi, 2015). Perubahan tersebut mengindikasikan adanya peningkatan CBF KC ibu dalam aliran darah otak, sehingga dapat mempengaruhi struktur dan meningkatkan perkembangan otak bayi prematur (Korraa et al., 2014).

KC mengurangi bradikardia dan kejadian desaturasi oksigen pada bayi prematur, memberikan stabilitas fisiologis dan kemungkinan manfaat untuk hasil perkembangan saraf (Mitchell et al., 2013). KC membantu dalam mengurangi efek nyeri akibat tusukan tumit yang menyakitkan pada bayi prematur. Dengan KC, bayi mengalami keseimbangan yang lebih baik yang ditunjukkan oleh stabilitas yang lebih otonom selama prosedur tongkat berjalan tumit (Cong et al., 2009).

Nyeri tumit secara signifikan lebih jarang terjadi pada bayi prematur yang menerima pengobatan KMC. Dilihat dari 30 menit setelah perawatan KMC, kejadian tusukan tumit secara signifikan lebih rendah (Chidambaram et al., 2014). Efek KMC pada skor nyeri juga secara signifikan lebih rendah setelah nyeri tumit di KMC pada 60 detik (Choudhary et al., 2016). Efek analgesia KC ibu berulang tetap stabil pada bayi prematur dibandingkan dengan prosedur nyeri berulang (Gao et al., 2015). 


\section{Manfaat bagi orang tua bayi}

Selama SSC, kadar PL saliva ibu, ayah dan bayi meningkat secara signifikan. Orang tua menjadi lebih terlibat dengan bayi mereka. Metode ini merupakan tindakan efektif untuk meminimalkan stres pada orang tua dan bayi. SSC merupakan pendekatan untuk meningkatkan respons dan sinkronisasi dalam interaksi orang tua-bayi (Vittner et al., 2018).

Tingkat respirasi antara kedua kelompok sangat berbeda. Kelompok eksperimen memiliki skor kelekatan ibu-bayi yang lebih tinggi daripada kelompok kontrol. KC menunjukkan hasil positif yang signifikan terhadap keseimbangan fungsi fisiologis bayi (Cho et al., 2016).

Intervensi yang efektif untuk mengurangi stres bagi orang tua dan bayi di NICU adalah metode SSC. SSC dapat memajukan eksplorasi OT sebagai moderator untuk meningkatkan hubungan dan interaksi orang tua-bayi (Vittner et al., 2018). KC menunjukkan bahwa kontak fisik dapat meningkatkan keterikatan ibu-bayi dan mengurangi stres ibu (Cho et al., 2016).

\section{Manfaat dalam proses menyusui pada bayi}

Kenaikan berat badan dan tingkat menyusui kelompok KMC secara signifikan lebih tinggi. KMC meningkatkan pertumbuhan fisik dan angka menyusui, serta metode ini diterima dengan baik oleh ibu dan perawat staf (Gathwala, Singh and Singh, 2010).

Bayi prematur yang mendapat KC dapat mencapai full enteral feeding dengan lebih cepat, bayi juga lancar minum ASI, suhu bayi tetap seimbang, dan aliran darah ke otak lancar (ElFarrash et al., 2019). Peningkatan pemberian ASI adalah 4,1 kali lipat. Metode pengobatan prematur ini aman, efektif, dan cocok untuk digunakan di NICU (Heidarzadeh et al., 2013). Perlu ditekankan praktik kontak fisik sejak usia dini saat bayi PT lahir karena memberikan hasil yang positif pada frekuensi dan inisiasi menyusui di NICU (NielaVilén et al., 2016).

\section{Kesimpulan}

Hasil scoping review didapatkan 4 efektifitas perawatan kanguru pada bayi prematur, yaitu Implementasi yang mudah, manfaat pada fisik bayi, manfaat bagi orang tua bayi, dan manfaat dalam proses menyusui pada bayi. Pelaksanaan perawatan kanguru pada bayi prematur dapat memberikan manfaat pada bayi, terutama terhadap fisik bayi.

Studi ini telah memberikan review terkait Efektifitas Perawatan Kanguru Pada Bayi Prematurdi Negara maju dan berkembang, namun peneliti menemukan adanya gaps dalam studi ini, diantaranya penelitian tentang efektifitas perawatan kanguru pada bayi prematur masih sedikit.

\section{Daftar Pustaka}

Benoit, B. et al. (2016) 'Staff nurse utilization of kangaroo care as an intervention for procedural pain in preterm infants', Advances in Neonatal Care, 16(3), pp. 229238. doi: $10.1097 /$ ANC. 0000000000000262.

Bera, A. et al. (2014) 'Effect of kangaroo mother care on growth and development of low birthweight babies up to 12 months of age: A controlled clinical trial', Acta Paediatrica, International Journal of Paediatrics, 103(6), pp. 643-650. doi: 10.1111/apa.12618.

Bettany, J. and Saltikov (2012) How to Do a Systematic Literature Review in Nursing: A Step-By-Step Guide - Josette BettanySaltikov - Google Buku.

Carlo, W. A. et al. (2010) 'Newborn care training of midwives and neonatal and perinatal mortality rates in a developing country', Pediatrics, 126(5). doi: 10.1542/peds.20093464.

Charpak, N. et al. (2017) 'Twenty-year follow-up of kangaroo mother care versus traditional care', Pediatrics, 139(1). doi: 10.1542/peds.2016-2063.

Chidambaram, A. G. et al. (2014) 'Effect of Kangaroo mother care in reducing pain due to heel prick among preterm neonates: A crossover trial', Journal of Maternal-Fetal and Neonatal Medicine, 27(5), pp. 488-490. doi: 10.3109/14767058.2013.818974.

Cho, E. S. et al. (2016) 'The Effects of Kangaroo Care in the Neonatal Intensive Care Unit on the Physiological Functions of Preterm Infants, Maternal-Infant Attachment, and Maternal Stress', Journal of Pediatric Nursing. W.B. Saunders, 31(4), pp. 430-438. doi: 10.1016/j.pedn.2016.02.007. 
Choudhary, M. et al. (2016) 'To study the effect of Kangaroo Mother Care on pain response in preterm neonates and to determine the behavioral and physiological responses to painful stimuli in preterm neonates: A study from western Rajasthan', Journal of Maternal-Fetal and Neonatal Medicine. Informa UK Ltd, 29(5), pp. 826-831. doi: 10.3109/14767058.2015.1020419.

Colquhoun, H. L. et al. (2014) 'Scoping reviews: Time for clarity in definition, methods, and reporting', Journal of Clinical Epidemiology. Elsevier Inc, 67(12), pp. 1291-1294. doi: 10.1016/j.jclinepi.2014.03.013.

Cong, X. et al. (2009) 'Kangaroo Care modifies preterm infant heart rate variability in response to heel stick pain: Pilot study', Early Human Development. Elsevier Ireland Ltd, 85(9), pp. 561-567. doi: 10.1016/j.earlhumdev.2009.05.012.

Daudt, H. M. L., Van Mossel, C. and Scott, S. J. (2013) 'Enhancing the scoping study methodology: A large, inter-professional team's experience with Arksey and O'Malley's framework', BMC Medical Research Methodology, 13(1), pp. 1-9. doi: 10.1186/1471-2288-13-48.

El-Farrash, R. A. et al. (2019) 'Longer duration of kangaroo care improves neurobehavioral performance and feeding in preterm infants: a randomized controlled trial', Pediatric Research. Springer US, (June). doi: 10.1038/s41390-019-0558-6.

Feldman, R., Rosenthal, Z. and Eidelman, A. I. (2014) 'Maternal-preterm skin-to-skin contact enhances child physiologic organization and cognitive control across the first 10 years of life', Biological Psychiatry. Elsevier, 75(1), pp. 56-64. doi: 10.1016/j.biopsych.2013.08.012.

Gao, Haixia et al. (2015) 'Effect of repeated Kangaroo Mother Care on repeated procedural pain in preterm infants: A randomized controlled trial', International Journal of Nursing Studies. Elsevier Ltd, 52(7), pp. 1157-1165. doi: 10.1016/j.ijnurstu.2015.04.006.

Gathwala, G., Singh, J. and Singh, B. (2010) 'Article Care on physical growth', (October), pp. 199-203.
Heidarzadeh, M. et al. (2013) 'The Effect of Kangaroo mother care (KMC) on breast feeding at the time of NICU discharge', Iranian Red Crescent Medical Journal, 15(4), pp. 302-306. doi: 10.5812/ircmj.2160.

Karlsson, V. et al. (2012) 'Early Skin-to-Skin Care in Extremely Preterm Infants: Thermal Balance and Care Environment', The Journal of Pediatrics, 161(3), pp. 422-426. doi: https://doi.org/10.1016/j.jpeds.2012.02.034

Korraa, A. A. et al. (2014) 'Impact of kangaroo mother care on cerebral blood flow of preterm infants', Italian Journal of Pediatrics, 40(1), pp. 1-6. doi: 10.1186/s13052-014-0083-5.

Leclersscq, V. et al. (2019) 'Meta-analyses indexed in PsycINFO had a better completeness of reporting when they mention PRISMA', Journal of Clinical Epidemiology, 115, pp. 46-54. doi: 10.1016/j.jclinepi.2019.06.014.

Mitchell, A. J. et al. (2013) 'Effects of daily kangaroo care on cardiorespiratory parameters in preterm infants', Journal of Neonatal-Perinatal Medicine, 6(3), pp. 243249. doi: 10.3233/NPM-1370513.

Morlacchi, L. et al. (2018) 'Protein use and weightgain quality in very-low-birth-weight preterm infants fed human milk or formula', American Journal of Clinical Nutrition, 107(2), pp. 195-200. doi: 10.1093/ajcn/nqx001.

Mudiyah, S. and Pratomo, H. (2016) 'Perawatan Metode Kanguru Pada Bidan Di Kabupaten Musi Rawas Sumatera Selatan Tahun 2016', pp. 128-141.

Munn, Z. et al. (2018) 'Systematic review or scoping review? Guidance for authors when choosing between a systematic or scoping review approach', BMC Medical Research Methodology. BMC Medical Research Methodology, 18(1), pp. 1-7. doi: 10.1186/s12874-018-0611-x.

Ndelema, B. et al. (2016) 'Low-tech, high impact: Care for premature neonates in a district hospital in Burundi. A way forward to decrease neonatal mortality', BMC Research Notes. BioMed Central, 9(1), p. 1DUUMY. doi: 10.1186/s13104-015-1666-y. 
Niela-Vilén, H. et al. (2016) 'Predictors of Breastfeeding Initiation and Frequency for Preterm Infants in the NICU', JOGNN Journal of Obstetric, Gynecologic, and Neonatal Nursing. Elsevier Inc, 45(3), pp. 346-358. doi: 10.1016/j.jogn.2016.01.006.

Ningsih, S. R., Suryantoro, P. and Nurhidayati, E. (2020) 'Hubungan pengetahuan ibu tentang perawatan bayi berat lahir rendah (BBLR) dengan kenaikan berat badan bayi', Jurnal Kebidanan dan Keperawatan Aisyiyah, 12(2), pp. 149-157. doi: 10.31101/jkk.306.

Parsa, P. et al. (2018) 'The effect of kangaroo mother care on physiological parameters of premature infants in Hamadan city, Iran', Pan African Medical Journal, 30, pp. 1-8. doi: 10.11604/pamj.2018.30.89.14428.

Pham, M. T. et al. (2014) 'A scoping review of scoping reviews: Advancing the approach and enhancing the consistency', Research Synthesis Methods, 5(4), pp. 371-385. doi: 10.1002/jrsm.1123.

Ramani, M. et al. (2018) 'Kangaroo mother care for the prevention of neonatal hypothermia: $A$ randomised controlled trial in term neonates', Archives of Disease in Childhood, 103(5), pp. 492-497. doi: 10.1136/archdischild-2017-313744.

Rusmania, N. (2015) 'No Title空間像再生型立体映像の 研究動向', Nhk技研，151， pp. 10-17. doi: 10.1145/3132847.3132886.

Sofiani, F. and Asmara, F. Y. (2014) 'Pengalaman Ibu Dengan Bayi Berat Lahir Rendah (Bblr) Mengenai Pelaksanaan Perawatan Metode Kanguru (Pmk) Di Rumah', Prosiding Seminar Nasional, 2(2). Available at: http://jurnal.unimus.ac.id/index.php/psn12 012010/article/view/1467.

Vittner, D. et al. (2018) 'Increase in Oxytocin From Skin-to-Skin Contact Enhances Development of Parent-Infant Relationship', Biological Research for Nursing, 20(1), pp. 54-62. doi: 10.1177/1099800417735633.

Yelmi, S. (2015) 'Pengaruh Perawatan Metode Kanguru terhadap Perubahan Berat Badan Bayi Lahir Rendah', Jurnal Ipteks Terapan, 9(1), pp. 11-19. doi: 10.22216/jit.2015.v9i1.24. 